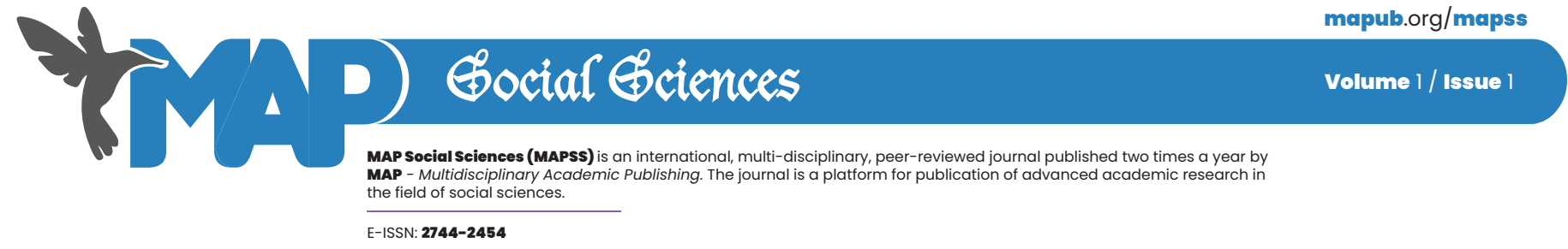

ORIGINAL RESEARCH PAPER

\title{
TEACHING LEXICAL CHUNKS IN THE ONLINE ENGLISH LANGUAGE CLASSROOM THROUGH LEARNING MANAGEMENT SYSTEMS
}

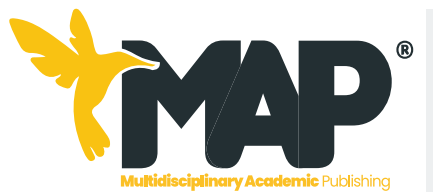

MAP SOCIAL SCIENCES

Volume 1 / Issue

ISSN: 2744-2454/ (c) 2021 The Authors. Published by MAP - Multidisciplinary Academic Publishing.

Article Submitted: 01 August 202 Article Accepted: 20 August 202 Article Published: 03 September 202

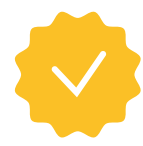

Publisher's Note: MAP stays neutral with regard to jurisdictional claims in published

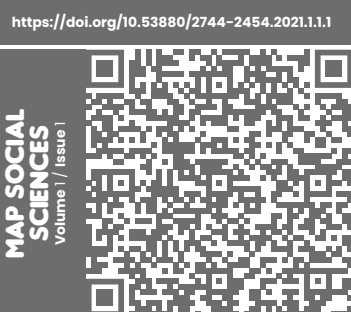

\author{
Marie Deissl-O'Meara' (i) , Isabella Tinkel² (i) \\ University of Applied Sciences Burgenland, Eisenstadt, Austria \\ ${ }^{2}$ University of Applied Sciences Burgenland, Eisenstadt, Austria
}

Correspondence concerning this article should be addressed to Isabella Tinkel, University of Applied Sciences Burgenland, Eisenstadt, Austria. E-mail: isabella.tinkel@epic-training.at

\section{ABSTRACT}

Current educational trends, globalization and the global Covid-19 pandemic have forced institutions of higher education (HEI) worldwide to accelerate the changes already in progress in teaching and learning approaches incorporating more technological enhanced learning. Among the wide range of information-communication-technology tools, the focus here is on Learning Management Systems (LMS), which play a major role in teaching and learning pedagogy, and can help HEls to achieve more effective learning outcomes. This exploratory research examines the usage of Learning Management Systems to support the teaching of lexical chunks in the online English language classroom at HEls. The investigation will focus on Moodle and will identify the factors that support students' interaction with language content and input in this digital learning environment, by looking at the use of Moodle features and activities to teach and practice lexical chunks. Findings suggest that Moodle proves of great value for online English language teaching and the practice of lexical chunks, whereby quiz activities can be used to great effect, producing motivation to engage with lexical chunks among students.

Keywords: English language learning, lexical approach, digital learning environment, learning management systems, learner autonomy 


\section{Gocial Giences \\ by MAP - Multidisciplinary Academic Publishing}

TEACHING LEXICAL CHUNKS IN THE ONLINE ENGLISH LANGUAGE CLASSROOM THROUGH LEARNING MANAGEMENT SYSTEMS

Marie DeissI-O'Meara and Isabella Tinkel

\section{Introduction}

The purpose of this exploratory research is to examine the yet rather unexplored topic of whether the usage of Moodle activities can support the teaching of lexical chunks in the English language teaching and learning environment. There have been studies exploring the possibilities information-communication-technology offers for learning vocabulary (e.g. Savuran \& Elibol, 2015) but little research (e.g. Seesink, 2007) has yet been done on lexical chunks specifically.

Covid-19 brought monumental challenges for higher education worldwide and, thus, online learning through Learning Management Systems (LMS), such as Moodle, has become an indispensable tool for teachers and students alike (Gonzalez-Vera, 2016). Although not originally designed for language teaching, Moodle has been found to show several clear advantages. It boosts student-centered learning and increases autonomy since the platform is available to the student at any time and from virtually any location. Moreover, the current generation of students at Universities of Applied Sciences is already very tech-savvy and well familiar with online learning platforms as the vast majority of these students belongs to the e-generation which is defined as a group of students who has "spent their entire lives surrounded by and using computers, videogames, digital music players, video cams, cell phones, and all the other toys and tools of the digital age" (Prensky, 2001 , p. 1 as cited in Gonzalez-Vera, 2016, p. 52). This, in turn, benefits teachers who play a pivotal role in producing content, designing didactic activities and implementing different technological tools (Gramp, 2013) that have the potential to increase student engagement in activities inside and outside classroom time compared to traditional classroom settings (Suppasetseree \& Dennis, 2010). It is this creation of online tasks suitable for the teaching of lexical chunks that will be explored by focusing on the following research questions:

1. Can the use of Moodle activities support the teaching of lexical chunks?

2. Which activity types are most suitable for teaching lexical chunks?

\section{Literature review}

\section{The Importance of Lexical Chunks for Language Learning}

Lexical chunks are word pairs or entire phrases that co-occur frequently, e.g. 'empirical research' or 'conduct a study'. They are a concept originating from the Lexical Approach which was established by Michael Lewis' in 1993 and belongs to the category of functional language teaching approaches. All approaches subsumed in this category place emphasis on meeting the needs of the language learner through providing "pieces" of language - or chunks - that fulfill specific linguistic and communicative purposes. This was the primary goal of Wilkins' (1972) notional syllabus. Extending this idea, Task-based Language Teaching is designed to give learners a concrete situation and the need to use certain language chunks to achieve a communicative goal (Larsen-Freeman \& Marti, 2014). Successful communication is also at the heart of the Natural Approach (Krashen \& Terrell, 1983) which emphasizes the importance of learners' understanding of the phrases and sentences of the target language in order to engage in meaningful verbal exchanges. All these concepts place lexis at the core of successful language learning, as does the Lexical Approach whose main idea is that language is composed of more or less fixed prefabricated chunks of language (Lewis, 1997).

It is as Wilkins (1972, p.l11f) stated, "while without grammar very little can be conveyed, without vocabulary nothing can be conveyed". Thus, the most crucial part in learning a language is establishing a solid vocabulary base. That is why lexical competence is often automatically associated with how many words a learner knows. However, learners' size of vocabulary (the number of words) has been found to be an insufficient indicator for any assessment of lexical proficiency. This is the case because knowledge of the existence of a word does, by no means, end with that isolated item. On the contrary, it extends far beyond that and, thus, a much better indicator for lexical and linguistic competence is the scope (or depth) of vocabulary a learner has. It is crucial to be aware of the context and co-text a given word exists in, as well as its numerous possible meanings depending on such context and co-text (Supasiraprapa, 2019). The more lexical chunks - i.e. a word including its co-text and context - learners know, the more they will use the language in an authentic and accurate 
fashion, including correct grammar. In fact, Lewis states that "a central element of language teaching is raising students' awareness of, and developing their ability to 'chunk' language successfully" (Lewis, 2012, p. vi). This idea has been supported by educator Barbara Oakley who is convinced that chunking any kind of information is one of the most valuable skills to improve learning in general. By chunking information it becomes possible for learners to increase memorization and recall prefabricated chunks more easily (Exeter, 2016).

Apart from the more obvious benefit of knowing as many lexical items as possible in a given language, lexical chunks are even more crucial than isolated vocabulary items. This is, in part, due to the facilitative nature of chunks when it comes to information retention and recall (Exeter, 2016), as mentioned above, but also because lexical chunks provide language learners with a variety of ready-made language items which accelerates language learning (Dervić \& Bećirović, 2020). Moreover, especially lower level learners might experience more enjoyment and less stress if they have fixed lexical chunks at their disposal and so not have to worry about making mistakes as much as they might otherwise (Rizvić \& Bećirović, 2017). Yet, language learners are often not used to viewing language in this way - as chunks. They are used to the well-established division of vocabulary and grammar (Kovačević et al., 2018), often with a focus on the latter. However, a shift in learners' mindset towards the value of lexical chunks is crucial in order to give them the tools to discover linguistic patterns and meaning more fully and independently (Lewis, 2012; Nattinger \& DeCarrico, 1992). Conveying the existence and usefulness of lexical chunks to learners can yield a multitude of other benefits apart from reducing potential frustration with those collocations or (fixed) expressions which do not seem logical when viewed through the lens of the learner's mother tongue (Kryszewska, 2003). By shifting learners' focus from isolated vocabulary items to common prefabricated chunks of language their active and passive command of the target language can be enhanced. This can be done by exposing learners to receptive as well as productive collocation-focused tasks as demonstrated in research by Falahi and Moinzadeh (2012) and Webb and Kagimoto (2009). Both studies showed a significant improvement in lexical chunks knowledge in the experimental group. Other studies highlight the positive effects of teaching collocations/lexical chunks. Abdellah
(2015) found that university students in Egypt who were exposed to a teaching program with a focus on the teaching of collocations outperformed their colleagues in the control group significantly. In the same vein, it was found that teaching collocations improves writing skills (Zhou \& Dai, 2016). It has also been proven that learners benefit from being explicitly taught about the nature of collocations in addition to being taught the collocations themselves. Fan (2005) discovered that learners' increased level of attention explicitly paid to verbnoun collocations is related to better performance in the areas of recall, production and detection of collocations. Likewise Seesink (2007) confirmed that the explicit teaching of collocations does help learners improve their skills - in her specific study, writing skills. Similarly, studies conducted among Algerian freshmen (Debabi \& Guerroud, 2018) and Iraqi college students (Abdulqader et al., 2017) revealed that using teaching programs that focus on raising awareness of collocations contributed to accuracy of collocations in students' writing.

While the majority of these studies were done in face-to-face settings and with more traditional offline teaching tools - except Seesink's (2007) - the paper at hand focuses on the teaching of lexical chunks in a $100 \%$ online English course necessitated by the Covid-19 pandemic.

\section{Digitalization Acceleration and Challenges for Higher Education in the Covid-19 Crisis}

Digitalization of modern education has received even more attention and become even more ubiquitous due to the transition to emergency remote teaching, instigated by the Covid-19 crisis, affecting universities worldwide and leading to significant challenges for the global higher education community. Jandrić (2020) emphasizes that digitalization, as experienced during the pandemic, is a form of forced digitalization of both teaching and learning, and is clearly a topic of paramount importance. Great interest has been placed on the use of technology during the past few years and in a study conducted by the Times Higher Education (Matthews, 2018), in spring 2018, the results showed that $19 \%$ of the interviewees believe that by 2030 digital technology will have replaced traditional classroom instruction. However, of the 200 respondents, all of whom were rectors from the top 1000 universities, $65 \%$ disagreed claiming that physical lectures still have a bright future despite 
the surge of digital disruption. The respondents from 45 countries and from across six continents were skeptical about the role digital learning will play in the future. On the other hand, $63 \%$ contended that traditional and esteemed universities will be offering online degrees by 2030 , compared with just $19 \%$ who will not. $24 \%$ believed that degree courses offered online will be more popular than courses taught on campus, while $53 \%$ disagreed. In spring 2018 , at the time of the survey there were only a few distancelearning universities. Most European universities were traditional non-distance universities, offering face-to-face teaching. The respondents did not believe that online teaching will be able to match the quality offered in face-to-face teaching and in spring 2018 still saw it as a quirk that every now and then receives more attention. Nevertheless, there was some consensus on the traditional lecture being outdated, claiming that online teaching facilitates a better learning experience. There is very little evidence to support the view that face-to-face teaching is superior and in a meta-analysis carried out by Bernard et al., (2014) it is stated that from a learning perspective there is no empirical evidence to show that the learning achievement of students is better in a classroom-based learning setting, compared to alternatives. This was contrary to the widespread belief of educators who had been convinced that online courses must be of poorer quality. In fact one of the conclusions drawn by Bernard et al. (2014) was that the medium is far less important that the quality of the pedagogy. Hoskins describes the difference between traditional faceto-face learning and online learning as "The way the content is delivered" (Hoskins, 2010, p. 4 as cited in Alhothli, 2015, p. 5). He then adds that the "new norm" will be online education (Hoskins, 2010, p. 4 as cited in Alhothli, 2015, p. 5). Thus, the goal of educational institutions must be to capture and challenge the imagination, based on learners' preexisting knowledge - that is what works, whether it is in the classroom or online.

As has been pointed out above, in early 2020 the Covid-19 crisis raised significant challenges for higher education (HE) worldwide. As an outcome of measures taken by educational institutions, the education of more than 1.5 billion students of all ages in countries all over the world was interrupted. Thus, $90 \%$ of the global student population was forced into some form of emergency remote education (UNESCO, 2020b, 2020a; UNICEF, 2020). The term emergency remote education (ERE) was coined as an umbrella term to include distance education, e-learning, online education, homeschooling etc. According to Bozkurt (2020), all of these terms derive from the term distance education, but it is pointed out that the main distinction between distance education and emergency remote education is that the latter refers to an obligation, whereas the former refers to an option. Emergency remote education is, as the term suggests, a survival strategy adopted at the beginning of the pandemic in an attempt to ensure the continuity of education. Distance learning, in contrast, is planned and put into practice on the basis of both theoretical and practical knowledge, in a specific field, whereas emergency remote education does, per se, not have a pedagogical concept, which is a major challenge (Bozkurt, 2020).

As stated earlier, the onslaught of Covid-19 saw many universities concentrating on shifting content to an online environment, but very often without an explicit online pedagogy. Crawford et al., (2020) carried out a Covid-19 intra-period study by means of a desktop analysis, using both university and government sources $(n=172)$ to present responses of higher education intuitions to Covid-19. The analysis examining the different approaches of HE in 20 countries highlights the responses and different approaches. Countries were chosen from the six regions defined by the World Health Organization (2020 as cited in Crawford et al., 2020), in order to achieve equality, with at least two countries being chosen from each region. The countries selected are shown below.

Table 1:

Selected regions acc. to the WHO

\begin{tabular}{ll}
\hline Region & Countries \\
\hline African region & Nigeria, South Africa \\
Eastern Mediterranean region & Egypt, Jordan, United Arab Emirates \\
European region & Germany, Ireland, Italy, United Kingdom \\
Region of the Americas & Brazil, Chile, United States of America \\
South-East Asia region & India, Indonesia \\
Western Pacific region & Australia, China, Hong Kong, Malaysia, Republic of \\
& Korea (South Korea), Singapore \\
\hline
\end{tabular}

As a result of this analysis it is clear that HE institutions reacted in very different ways, ranging from some institutions showing no response to the pandemic, whereas others implemented social isolation strategies, or even adapted the curriculum to facilitate online teaching. However, the researchers also highlight the lack of information on the pedagogical approaches behind the measures taken and suggest that exploring this aspect could provide scope for more "flexible and innovative digital methods of education" (Crawford et al., 2020 , p. 12). One such digital method that is highly 
useful in exploring these new ways of teaching are Learning Management Systems (LMS).

Learning Management Systems (LMS) and English Foreign Language Teaching

A Learning Management System (LMS) can either be a web-based or cloud based software program whose purpose is to support the teaching and learning process. Popular examples of LMSs are Moodle, Canvas, Blackboard, Edmodo, Google Classroom, etc. Technically defined, a Learning Management System is "a software application that automates the administration, documentation, tracking, reporting" and "facilitates the delivery of e-learning education courses or training programs" (Ellis, 2009, p. 2). In transitioning to online emergency remote education, UASs, pedagogical universities, public and private universities alike have relied heavily on LMSs (e.g., Moodle, Canvas, Blackboard, Edmodo, Google Classroom, etc.), synchronous communication, conferencing tools (e.g., Zoom, Microsoft Teams, Google Meet, Webex, etc.) and live broadcasting features of social networking sites (e.g., Facebook Live, Instagram Live, YouTube etc.) to counteract teaching disruptions (Bozkurt, 2020).

Moodle is one of the LMS systems that has been gaining increasing worldwide popularity. The word Moodle is an acronym for Modular ObjectOriented Dynamic Learning Environment which was first released in 2002. The mastermind behind Moodle is its founder and CEO Martin Dougiamas, who himself learned by distance education through radio. Based on his experience he saw the need for an online platform for educators to assist them in creating personalized learning environments. Today Moodle is an open source e-learning platform and its modular design allows content experts to develop additional functionalities. One of the great advantages of Moodle, as an open source product, is that it is not only free to be used, but can also be modified. The aim of Moodle is to assist those in the educational profession to design courses, which can be taught online, in a non-traditional teaching environment, but are based on traditional classroom-like interactions, while having a strong focus in the creation of collaborative content. It offers multiple opportunities for interaction and it provides the opportunity for both student-student and student-teacher interaction. Recent Moodle statistics show that Moodle now has over 200 million users from 247 countries, with currently a total number of 37 million courses. In March 2020, 50,000 additional new sites were registered (Moodle, n.d.). With a global market share of $14 \%$ Moodle is not the most frequently used LMS software - that would be Google Classroom with 39\% (Sadler, 2021) - but it is the most dominant software used in Austrian Universities of Applied Sciences with 19 of 21 using it and 1,384 registered Moodle sites within the country (Moodle, n.d.). Regarding the general experience with e-learning, a study carried out at the Graz University of Technology (TU Graz) found that Universities of Applied Sciences in Austria had already been using learning management systems by 2015 (Ebner et al., 2020). 50\% of UASs had had experience with e-learning for more than ten years at that point and $40 \%$ of UASs had employed e-learning for six to ten years. Only the remaining $10 \%$ had had experience of only one to five years.

Moodle was not explicitly designed for language instruction, however, it does lend itself to both EFL teaching and learning. Based on a constructivist approach it empowers active and flexible learning and facilitates a collaborative learning process which makes it possible for students and teachers to incorporate collaborative activities into the teaching-learning process (Coicaud, 2016; Silva, Fernández, \& Astudillo, 2014; Silva et al., 2016 as cited in Cabero-Almenara et al., 2019, p. 27). Some of the tools open for use on Moodle are forums, live chats, student quizzes, wikis, surveys, student workshops, questionnaires, glossaries, databases, feedback tools, and tools for providing asynchronous interactive content. Many instructors may use further tools such as the gamebased tool Kahoot, or indeed mindmaps, blogs, YouTube videos, etc. Additional statistics taken from Moodle Statistics, which are publicly available and updated in real time, show that in the months May and June 2021

- one new country has registered their first ever Moodle site

- eight million forum posts have been made

- nine million new resources have been added

- three million new users have joined registered Moodle sites

- thirty million new enrolments have taken place

- one million new courses have been added to Moodle sites.

One particularly interesting finding for the paper at hand is the worldwide increase in the number of quiz questions being added to Moodle on 
a daily basis assisting educators to find alternative forms of assessment during the pandemic. Current figures show that the global Moodle Community and Moodle HQ now have 1,524,867,487 quiz questions hosted in all registered Moodle sites worldwide (Moodle, n.d.).

As mentioned before, Moodle was originally designed for distance learning but not specifically for EFL teaching. However, it can offer helpful and motivating tools for teaching language. It offers many benefits for tutors and students alike in a distant learning environment. The advantages of using Moodle for distant learning are akin to the advantages of using it for EFL teaching. One of the primary pros is flexibility which mirrors the developments in education providing permanent access to learning materials, as is in keeping with the anytime-anywhere principle. This allows students to learn when they want, what they want, how they want and where they want. Communication between peers and tutors is flexible and gives students time to prepare their ideas or thoughts before they engage in forum discussions. Anonymity can also be an incentive for students to get involved in discussions. A further key advantage of Moodle in EFL is the access to multimedia tools and applications such as images, sounds and animations enabling students to practice all four language skills, both the receptive skills (listening and reading) and the active skills (speaking and writing). An additional valuable function of Moodle is synchronous and asynchronous teacher-student and student-student communication, which may take place in the form of chats and forums. Integrated quizzes, which can be used for formative assessment give students immediate feedback on their performance, but can also be used to great effect for language input and practice, which is the focus of the next section.

\section{Teaching and Learning Lexical Chunks through Moodle}

As far as could be detected, not much research has yet been done on the teaching and learning of lexical chunks supported by Moodle. Generally, however, in a 2010 study it was found that out of 213 students involved in an English language teaching course supported by Moodle $93 \%$ found that the integration of Moodle activities generally had a beneficial effect on their language learning experience (Suppasetseree \& Dennis). A study conducted at the Aleksandras Stulginskis
University in Lithuania (Urbonienè \& Koverienè, 2013) examined, among other topics, students' opinions on the usefulness of several Moodle activities used in a blended-learning course teaching the basics of business English. After two semesters students were asked to evaluate the course. Firstly, and more generally, $73 \%$ found that Moodle was helpful for language learning overall and $77 \%$ stated that Moodle had met their needs and that they would recommend it to other students. In terms of activities used, the researchers discovered that, among the selection of modules used, providing resources $(67 \%)$, assignments (59\%) and quizzes (57\%) scored the highest, whereas tools such as forums (28\%) and chats $(21 \%)$ received the lowest ratings. In an earlier study (Suppasetseree \& Dennis, 2010) in Thai tertiary education it was revealed that teachers tended to use Moodle first and foremost for administrative purposes such as the provision of learning materials and an overview of grades. Yet, they also used the quiz, journal and assignment functions in their courses. Moreover, the glossary was regarded as especially important for creating a vocabulary collection that all students could benefit from. In a 2016 study of 200 Spanish freshmen native speaker students learning English in a course supported by Moodle it was found that all of these students, who were part of the e-generation, already had some experience with e-learning platforms before the experiment and $64 \%$ were using some forms of English activities on the web to improve their language skills. Also, $75 \%$ reported that they preferred computer-based tasks to the exclusive use of traditional classroom exercises. After administration of the treatment, $70 \%$ of participants rated Moodle as helpful for their language learning. Moreover, all four skills saw an overall improvement after supporting students with Moodle. However, it must be pointed out that this perceived improvement was based on participants' self-assessment and that the institutional assessment in the form of end-of-term tests was yet outstanding at the time the research was published. The exact nature of the Moodle tasks used in the study also remains unknown (Gonzalez-Vera, 2016) but the general approval of e-learning and technology use by participants is certainly an indication that LMSs can contribute positively to language learning. Moodle was also used successfully by Seesink (2007) who used the LMS to support the study of collocation with focus on writing. Results showed that students' writing included more collocations after the course. Yet, when asked to evaluate the blended-learning 


\section{Gocial Giences \\ by MAP - Multidisciplinary Academic Publishing}

TEACHING LEXICAL CHUNKS IN THE ONLINE ENGLISH LANGUAGE CLASSROOM THROUGH LEARNING MANAGEMENT SYSTEMS

Marie Deissl-O'Meara and Isabella Tinkel

format of the course, students stated that they preferred the face-to-face classes and would rather use Moodle for review purposes. In 2015 Savuran and Elibol examined the effectiveness of using Moodle as a supplementary source to support vocabulary learning. The study included Bl-level students aged 18-24 from the preparatory classes at the School of Foreign Languages at Ankara University. The experimental group received tuition supported my Moodle activities while the control group did not work with online resources. Data on vocabulary knowledge was collected by administering a multiple choice test consisting of 105 questions based on vocabulary items from several units of the course book in use. Data analysis yielded that students who were taught with additional Moodle input reached a mean score of 58.7667 and, thus, performed significantly better on the vocabulary test than those who did not receive such input with a mean score of 45.7923 .

As can be seen Moodle has been shown to offer significant advantages concerning English language teaching. Among those is the fact that it allows for student-centered learning which means that students can practice anytime and anywhere once the learning materials and resources have been made available. For teachers, Moodle also facilitates administration and, in the present research, greatly facilitated the practice of lexical chunks compared to what could have been done in the face-to-face classroom sessions. Additionally, teachers can maintain an overview of the activities students have completed as well as the scores achieved (Suppasetseree \& Dennis, 2010). Naturally, using Moodle for language teaching entails some possible disadvantages as well. Among those that have been identified are the issues of technical competence or lack of confidence and knowledge regarding working with technology on the part of the teacher as well as the student (Saptopramono et al., 2018). Rapanta et al., (2020) warn about the dangers of a 'tool-based' approach and highlight that it does not provide the educator with any indication about how, when and why certain tools should be used. Thus, through the lack of a common, widely understood pedagogical framework for online teaching and learning, it remains generally unclear what additional pedagogical dimensions need to be considered in an online situation (Picciano, 2017). Research has been carried out that concludes that there is indeed greater use of LMS platforms but that there is no generalized evidence of a change in pedagogical practice (Brown, 2008;
Browne et al., 2006; Kinchin, 2012), where teachers tend to use it more to transmit knowledge than to develop, invent and create knowledge (Fariña et al., 2013). In addition research shows that many teachers only use a minimum of LMS's possibilities (Browne et al., 2010; Rienties, 2012). Hence, this paper examines one option of how to achieve the pedagogical goal of teaching lexical chunks using Moodle as a knowledge transfer and development tool to support students' long-term language learning process. However, it is clear that using Moodle and its activities efficiently and competently takes considerable training and competence on the part of the teacher to strengthen pedagogical and technological knowledge (Mishra \& Koehler, 2008) and also requires some explanation to the students (Rymanova et al., 2015; Suppasetseree \& Dennis, 2010) as the quality of the materials provided as well as the mentoring of students is a crucial success factor in online-assisted language learning (ParejaLora et al., 2016). However, students involved in the present research were already used to working with Moodle to a certain extent and, hence did not require extensive introductions or explanations in order to use the platform in the English class.

\section{Methodology}

Data was gathered in the summer semester of 2021 from three Business English courses of the same teacher working with three different groups of students $(n=39)$ at a University of Applied Sciences in Austria. All students were taught exclusively online and were given an introduction to the nature and usefulness of lexical chunks for their own language learning at the outset of the semester. Subsequently, Moodle was used extensively to support the detection and practice of lexical chunks from numerous topic areas in a variety of ways. Moodle activity types used by the teacher were recorded. Moreover, written and oral feedback regarding students' opinion of the suitability and usability of the Moodle tasks used to teach lexical chunks was obtained through questionnaires and interviews from a number of students. 


\section{Gocial Giciences \\ by MAP - Multidisciplinary Academic Publishing}

TEACHING LEXICAL CHUNKS IN THE ONLINE ENGLISH LANGUAGE CLASSROOM THROUGH LEARNING MANAGEMENT SYSTEMS

Marie DeissI-O'Meara and Isabella Tinkel

\section{Results and discussion}

\section{Research Question 1: Can the Use of Moodle Activities Support the Teaching of Lexical Chunks?}

Results (figure 1) show that, overall, 78.57\% of respondents regarded the Moodle tasks used to convey knowledge about and practice lexical chunks as (very) useful. This aligns with Urboniene and Koverienè's (2013) finding that their participants rated Moodle profitable for language learning in general. $14.29 \%$ regarded the tasks' usefulness as neutral and $7.14 \%$ said the Moodle activities were not useful.

\section{Figure 1:}

General usefulness of Moodle activities in \%

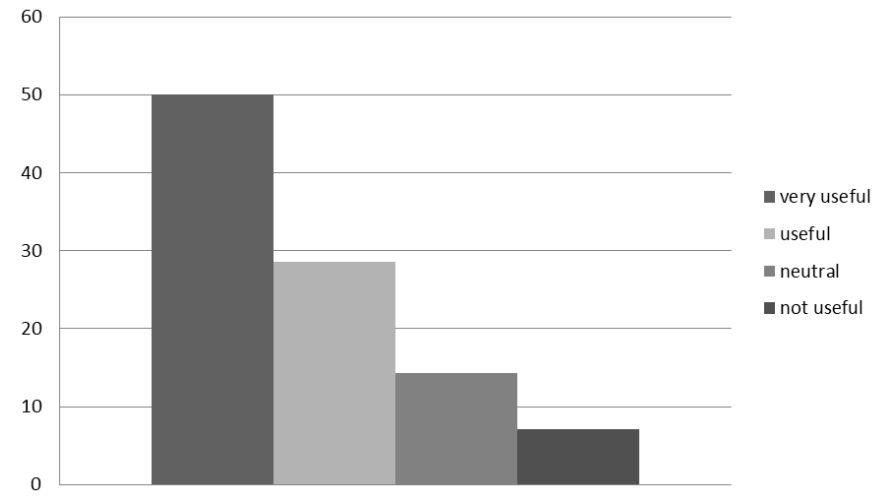

When analyzing the written statements regarding the ways in which the Moodle activities were useful or not in general, several categories emerged (figure 2). The most salient observation was that most respondents found that the Moodle activities employed were very helpful in practicing lexical chunks after having been introduced to the concept at the beginning of the semester. Several students stated that the Moodle exercises were generally supportive of language learning and also said that the game-like nature of the tasks was appealing. They also reported that these activities helped them extend the size and scope of their vocabulary - something that is crucial to improving language competence. Becoming more aware of lexical chunks through the Moodle tasks and the option to repeat tasks and practice outside class at their own speed were also rated as advantages. It was also pointed out that such explicit focus on lexical chunks and repeated practice of detecting them might actually diminish the actual value or the exercises. However, it is presumed that the one student who made this statement was referring to the fact that, due to their very high level of English proficiency, many lexical chunks were already known and it was easy for them to pick up new language anyway.

\section{Figure 2:}

Areas of perceived usefulness of Moodle activities (absolute numbers/participants)

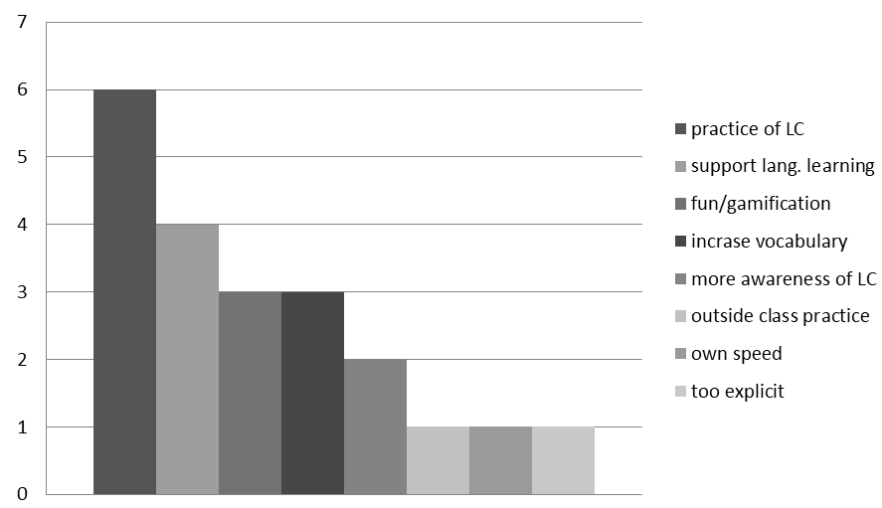

Research Question 2: Which Activity Types are Most Suitable for Teaching Lexical Chunks?

Over the course of the semester Moodle activities were used to teach lexical chunks primarily inside but also outside synchronous online English sessions. The activity type that proved most useful during lessons from the teacher's point of view was the quiz. This is due to the vast array of different subtasks this activity offers - some of which lend themselves perfectly to teaching and practicing lexical chunks. Similarly, the teacher used SCORM packages to integrate exercises designed in a different online application into the Moodle course. These exercises could be equated with the quiz function as they mostly feature the same subtasks used in the quiz. Therefore, quiz and SCORM packages have been subsumed under one category in figure 3, making up 50\% of all lexical chunk-related Moodle activities used in and outside class. As will be seen in the next section presenting the detailed analysis of the task types used, students were very appreciative of these tasks. This coincides with Suppasetseree and Dennis (2010) who measured that $97 \%$ of their participants found it helpful for language learning to complete Moodle quizzes as well as with GonzalezVera (2016) who reported that $90 \%$ of participants liked the self-assessment quizzes offered through Moodle. The teacher also made frequent use of the document upload function to provide students with information on lexical chunks or a summary of 


\section{Gocial Giences \\ by MAP - Multidisciplinary Academic Publishing}

TEACHING LEXICAL CHUNKS IN THE ONLINE ENGLISH LANGUAGE CLASSROOM THROUGH LEARNING MANAGEMENT SYSTEMS

Marie DeissI-O'Meara and Isabella Tinkel

chunks collected together in the session. Similar in nature is the option to share a link via Moodle and this was employed to give students direct and easy access to online collocations dictionaries. This was perceived as very helpful because students were given an additional resource to detect new word combinations themselves. Again Suppasetseree and Dennis, (2010) found that $93 \%$ of their students perceived the provision and download of information via Moodle as useful. Outside the sessions students were occasionally asked to complete several quiz tasks related to lexical chunks. Their main task was, however, to keep a lexical chunk journal through the journal activity available in Moodle. This was a compulsory component of the course and was well received by most students. The majority generated extensive lists of high-quality lexical chunks taken from the sessions or from other sources of input. One student specifically stated that they found this lexical chunk journal very important for the retention and constant practice of detecting lexical chunks because only if there is a certain extent of pressure to engage with this new view on language, can it be internalized successfully. Moreover, that same student very much appreciated the feedback the teacher gave on the lexical chunk journals at the end of each month. This allowed for everyone to know whether they were selecting good lexical chunks and where there was room for improvement. Another activity type used to give students practice outside class time was the assignment. This was used to provide instructions for writing short texts based on either students' own opinion or an audio file. In order to engage with lexical chunks, instructions either included certain node words that needed to be used in a correct lexical chunk in the text to be written or students had to highlight the lexical chunks they used in their texts on a specific topic. Such highlighting was also perceived as useful by students as it increased their awareness of new lexical chunks as well as of chunks they already knew.

\section{Figure 3:}

All activity types used in \% (inside and outside class)

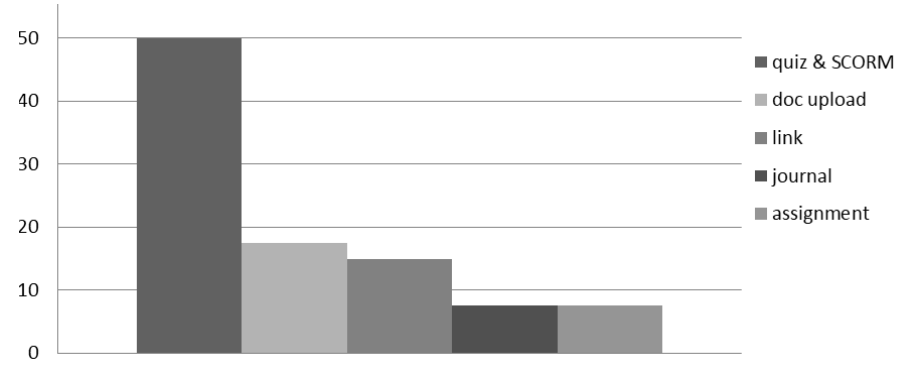

As the quiz and SCORM activity together amount to $50 \%$ of the tasks used (figure 4), a closer look was taken at which subtasks seem to be most useful from the teacher's point of view and what students' opinions were. It must be pointed out, however, that the majority of the task types mentioned here was used in the quiz activity. It was found that $50 \%$ of all tasks types were cloze exercises. These are generally comparable with traditional gap-fill exercises but, because of the interactive nature of Moodle, can be combined with video and audio material as well. This was done in class several times, along with cloze exercises that focused on the skill of reading and students expressed satisfaction with the interactive use of media. The aim of all tasks was to build students ability to recognize lexical chunks and isolate them correctly. Similarly useful was the task type of matching, accounting for $33.33 \%$ of all subtasks used. This is a more game-like engagement with lexical chunks and, as mentioned before, students enjoyed the part-gamification of language because it increased their enthusiasm and supported their learning, making working with lexical chunks easier as time passed. The subtask type titled 'description' (6.67\%) was used only to provide instructions for more self-directed engagement with lexical chunks such as giving node words and then students had to consult a collocation dictionary (alone or in small groups) to find useful and appropriate lexical chunks. Further subtasks used were drag and drop into image (3.33\%), which is comparable to matching in many aspects, and ordering (6.67\%), which was combined with videos and students were asked to focus on specific lexical chunks and to put them into the order that they occurred in the video.

\section{Figure 4:}

Activity subtypes used in \%

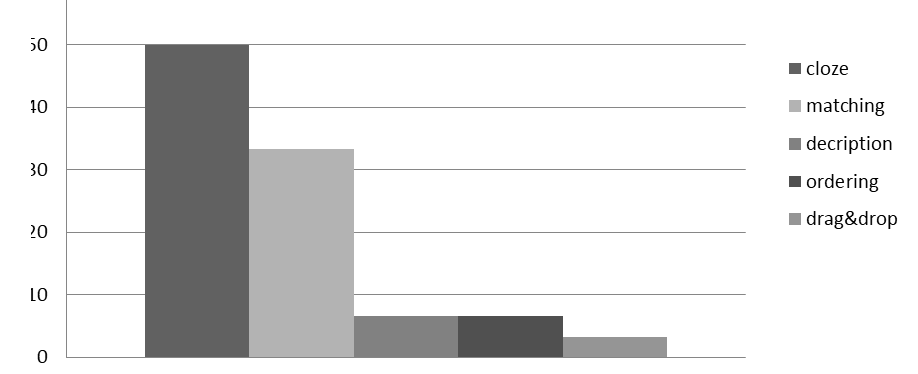


by MAP - Multidisciplinary Academic Publishing

TEACHING LEXICAL CHUNKS IN THE ONLINE ENGLISH LANGUAGE CLASSROOM THROUGH LEARNING MANAGEMENT SYSTEMS

Marie Deissl-O'Meara and Isabella Tinkel

\section{Conclusion}

The study presented found that Moodle activities are perceived as useful for the teaching and learning of lexical chunks by the teacher as well as by students. Learners reported that they profited most from the Moodle activities in four main areas - practicing lexical chunks, general feeling of support for language learning, increased motivation and engagement through gamification and the opportunity to increase their vocabulary size and scope. Additionally, some of the most suitable activity types were examined and the most frequently used quiz and SCORM activities were also rated as helpful by students. Within the quiz activity, the teacher found the cloze and matching subtasks most useful. Outside the classroom the journal activity proved of great value to maintain students' engagement with lexical chunks.

With reference to the perceived usefulness of glossaries by teachers in the study by Suppasetseree and Dennis (2010) it would surely be worth trying to integrate this activity in the next version of a Lexical Approach-based teaching program. Moreover, being able to track students' task completion and scores in Moodle could offer some interesting indications as to whether such a Lexical Approach-based teaching program shows the desired improvement in students who complete all activities with solid results. Savuran and Elibol (2015) found, in their study on the usefulness of supporting vocabulary learning through Moodle, that those students who scored highest on the vocabulary test were also those who logged into Moodle most frequently, while those who did not make regular use of the Moodle activities scored lowest on the vocabulary test. Moreover, continued use of Moodle activities in the language teaching classroom in general and especially to teach lexical chunks will improve teachers' ability to choose and use suitable resources and activities to achieve optimum outcome.

Conflict of interest: Marie Deissl-O'Meara and Isabella Tinkel declare that they have no conflict of interest.

\section{References}

Abdellah, A. S. (2015). The Effect of a Program Based on the Lexical Approach on Developing English Majors' Use of Collocations. Journal of
Language Teaching and Research, 6(4), 766. https://doi.org/10.17507/jltr.0604.08

Abdulqader, H. B., Murad, I. H., \& Abdulghani, M. I. (2017). The Impact of the Application of Lexical Approach on Developing Students' Writing Skills at a University Level. European Scientific Journal, ESJ, 13(32), 130. https://doi.org/10.19044/esj.2017. v13n32pl30

Alhothli, N. (2015). Investigating the impact of using moodle as and e-learning tool for students in an English language institute. University of Montana.

Bernard, R. M., Borokhovski, E., Schmid, R. F., Tamim, R. M., \& Abrami, P. C. (2014). A meta-analysis of blended learning and technology use in higher education: From the general to the applied. Journal of Computing in Higher Education, 26(1), 87-122. https://doi.org/10.1007/s12528-013-9077-3

Bozkurt, A. (2020). Educational Technology Research Patterns in the Realm of the Digital Knowledge Age. Journal of Interactive Media in Education, 2020(1), 18. https://doi.org/10.5334/ jime.570

Brown, S. (2008). From VLEs to Learning Webs- The Implications of Web 2. Interactive Learning Environments, 18(1), 1-10.

Browne, T., Hewitt, R., Jenkins, M., Voce, J., Walker, R., \& Yip, H. (2010). UCISA Survey. 2010 Survey of Technology Enhanced Learning for higher education in the UK. 2011(15 February), Online. http:// www.ucisa.ac.uk/groups/ssg/surveys.aspx

Browne, T., Jenkins, M., \& Walker, R. (2006). A longitudinal perspective regarding the use of VLEs by higher education institutions in the United Kingdom. Interactive Learning Environments, 14(2), 177-192. https://doi.org/10.1080/10494820600852795

Cabero-Almenara, J., Arancibia, M. L., \& Del Prete, A. (2019). Technical and didactic knowledge of the moodle LMS in higher education. Beyond functional use. Journal of New Approaches in Educational Research, 8(1), 25-33. https://doi. org/10.7821/naer.2019.1.327

Crawford, J., Henderson, K. B., Rudolph, J., Malkawi, B., Glowatz, M., Burton, R., Magni, P. A., \& Lam, S. (2020). COVID-19: 20 countries ' higher education 


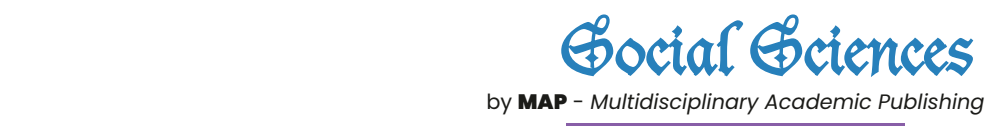

TEACHING LEXICAL CHUNKS IN THE ONLINE ENGLISH LANGUAGE CLASSROOM THROUGH LEARNING MANAGEMENT SYSTEMS

Marie DeissI-O'Meara and Isabella Tinkel

intra-period digital pedagogy responses. Journal of Applied Learning \& Teaching, 3(1), 1-20.

Debabi, M., \& Guerroud, N. j. (2018). The Lexical Approach in Action: Evidence of Collocational Accuracy and the Idiom Principle in the Writing of EFL Intermediate Students. Arab World English Journal, 9(3), 176-187. https://doi.org/10.24093/ awej/vol9no3.12

Dervić, M., \& Bećirović, S. (2020). Prerogative of the Lexical Approach in Communicative Language Teaching. European Journal of Education Studies, 7(3), 1-13. https://doi.org/10.5281/zenodo.3748039

Ebner, M., Schön, S., Braun, C., Ebner, M., Grigoriadis, Y., Haas, M., Leitner, P., \& Taraghi, B. (2020). COVID-19 epidemic as E-learning boost? Chronological development and effects at an Austrian university against the background of the concept of "E-learning readiness." Future Internet, 12(6). https://doi.org/10.3390/FI12060094

Ellis, R. K. (2009). A field guide to Learning Management Systems.

Exeter, J. A. (2016). Session with Barbara Oakley. Quora. https://writingsessions.quora.com/ Session-with-Barbara-Oakley

Falahi, M., \& Moinzadeh, A. (2012). Effects of Receptive and Productive Tasks on Iranian EFL Students' Learning of Verb-noun Collocations. Journal of Language Teaching and Research. https://doi.org/10.4304/jltr.3.5.953-960

Fan, Y. (2005). Differential effects of attention in second language acquisition of verb-noun collocations. Michigan State University.

Fariña, E., González, C. S., \& Area, M. (2013). ¿Qué uso hacen de las aulas virtuales los docentes universitarios? RED, Revista de Educación a Distancia, 35.

Gonzalez-Vera, P. (2016). The e-generation: the use of technology for foreign language learning. In A. Pareja-Lora, C. Calle-Martínez, \& P. RodríguezAracón (Eds.), New perspectives on teaching and working with languages in the digital era (pp. 51$61)$.
Gramp, J. (2013). Beyond the baseline: working with e-learning champions to transform e-learning at a research-led university. 2nd Moodle Research Conference, 2007(October 2013), 2432. http://research.moodle.net/mod/data/view. php?d $=7 \&$ rid $=123$

Jandrić, P. (2020). Postdigital Research in the Time of Covid-19. Postdigital Science and Education, 2(2), 233-238. https://doi.org/10.1007/ s42438-020-00113-8

Kinchin, I. (2012). Avoiding technologyenhanced non-learning. British Journal of Educational Technology, 43(2), 43-48. https://doi. org/10.1111/j.1467-8535.2011.01264.x

Kovačević, F., Amna, B.-Č., \& Bećirović, S. (2018). Opportunities and Challenges Facing Bosnian High-School EFL Learners. European Researcher, 9(4), 298-307. https://doi.org/10.13187/ er.2018.4.298

Krashen, S., \& Terrell, T. (1983). The Natural Approach. Language Acquisition in the Clasroom. Prentice Hall Europe.

Kryszewska, H. (2003). Why I won't say goodbye to the lexical approach. Humanising Language Teaching, 5(2), 1-11.

Larsen-Freeman, D., \& Marti, A. (2014). Techniques \& Principles in Language Teaching (3rd ed.). Oxford University Press.

Lewis, M. (1997). Implementing the Lexical Approach: Putting Theory Into Practice. Heinle Cengage Learning. https://doi.org/10.1017/ CBO9781107415324.004

Lewis, M. (2012). The lexical approach: The state of ELT and a way forward. Cengage Learning.

Matthews, D. (2018). How will technology reshape universitiy by 2030? Times Higher Education. https://www.timeshighereducation.com/features/ how-will-technology-reshape-university-2030

Mishra, P., \& Koehler, M. J. (2008). Introducing Technological Pedagogical Content Knowledge. The Language of Science Education, January, 106106. https://doi.org/10.1007/978-94-6209-497-0_95 


\section{Gocial Giciences \\ by MAP - Multidisciplinary Academic Publishing}

TEACHING LEXICAL CHUNKS IN THE ONLINE ENGLISH LANGUAGE CLASSROOM THROUGH LEARNING MANAGEMENT SYSTEMS

Marie DeissI-O'Meara and Isabella Tinkel

Moodle. (n.d.). Moodle Statistics. https:// stats.moodle.org

Nattinger, J. R., \& DeCarrico, J. S. (1992). Lexical Phrases and Language Teaching. TESOL Quarterly. https://doi.org/10.2307/3587319

Pareja-Lora, A., Calle-Martínez, C., \& Rodríguez-Aracón, P. (2016). New perspectives on teaching and working with languages in the digital era. In New perspectives on teaching and working with languages in the digital era. Reasearchpublishing.net. https://doi.org/10.14705/rpnet.2016. tislid2014.427

Picciano, A. G. (2017). Theories and frameworks for online education: Seeking an integrated model. Online Learning Journal, 21(3), 166-190. https://doi.org/10.24059/olj.v21i3.1225

Rapanta, C., Botturi, L., Goodyear, P., Guàrdia, L., \& Koole, M. (2020). Online University Teaching During and After the Covid-19 Crisis: Refocusing Teacher Presence and Learning Activity. Postdigital Science and Education, 2(3), 923-945. https://doi. org/10.1007/s42438-020-00155-y

Rienties, B. (2012). Integrating ICT in business education: Using TPACK to reflect on two course redesigns. In P. Van den Bossche, W. H. Gijselaers, \& R. G. Milter (Eds.), Learning at the Crossroads of Theory and Practice: Research on Innovative Learning Practices (Vol. 4, Issue March, pp. 1-249). Springer. https://doi.org/10.1007/978-94-007-2846-2

Rizvić, E., \& Bećirović, S. (2017). Willingness to Communicate in English as a Foreign Language in Bosnian-Herzegovinian EFL Context. European Researcher, 8(3), 224-235. https://doi.org/10.13187/ er.2017.3.224

Rymanova, I., Baryshnikov, N., \& Grishaeva, A. (2015). E-course Based on the LMS Moodle for English Language Teaching: Development and Implementation of Results. Procedia - Social and Behavioral Sciences, 206(November), 236-240. https://doi.org/10.1016/j.sbspro.2015.10.016

Sadler, M. (2021). 49 LMS Statistics and Trends for a Post-COVID World. TrustRadius. https:// www.trustradius.com/vendor-blog/Ims-statisticstrends
Saptopramono, H., Zaim, M., Ramadhan, S., \& Agustina, A. (2018). Practical Utilization of ICT in Adult Language Learning: Challenges and Barriers. May 2020. https://doi.org/10.2991/iclle-18.2018.12

Savuran, Y., \& Elibol, H. (2015). Teaching Vocabulary Items Using Moodle: Do They Learn Better? Journal of Media \& Mass Communication, 1(1), 84-89. https://doi.org/10.12720/jmmc.1.2.84-89

Seesink, T. (2007). Using blended instruction to teach academic vocabulary collocations: A case study. ProQuest Dissertations and Theses, 216. http://search.proquest.com/ docview/304799775? accountid=13042\%5Cnhttp:// oxfordsfx.hosted.exlibrisgroup.com/oxford?url ver $=z 39.88-2004 \& r f t \_v a l \_f m t=i n f o: o f i /$ 